\section{Danske 1500-tals bøger trykt på gult papir}

\author{
Affhv. skoleleder Peter E. Raes
}

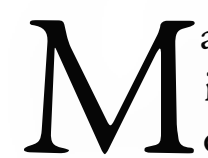
an kan næppe fortænke Liselotte $\mathrm{i}$, at hun blev noget forbavset over at høre mig udstøde et ret højt „Heureka“ midt i Museumsbygningens Kunstauktionslokaler på Østerbro, for et par år siden. Hun kendte mig slet ikke, og kunne ej heller vide, at jeg i over fire år forgæves havde forsøgt igennem breve og annoncer i svenske aviser at opspore et meget specielt eksemplar af Christian d. III's store kirkebibel fra 1550. Denne første udgave af hele Bibelen på dansk har spillet en overordentlig stor rolle i både vort religionsliv og sprogets udvikling, så eksemplarer af den er meget eftertragtet, især da der nu.kun findes omkring et par hundrede tilbage af de oprindelige 3000 .

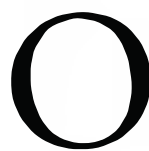
g så stod jeg pludselig dér med nogle notater, som hun havde rakt mig, hvori der stod: „Eksemplaret er på gult papir". Disse notater var oven $\mathrm{i}$ købet skrevet af en kendt københavnsk antikvar. Min søgen syntes endelig ved at være bragt til ende.

Hvad var det så for en sag, der allerede i 1993 havde vakt min interesse? Ikke mindre end dette højst usædvanlige eksemplar af den næsten 450 år gamle bibel - og så trykt på gult papir. Nok et unikum og givetvis af stor interesse for bogsamlere af tre grunde: For det første, at eksemplaret har tilhørt den store svenske bogsamler Per
Hierta først i sidste århundrede og stod nævnt i hans auktionskatalog fra 1932 efter hans død, for siden hen at forsvinde fra offentligheden i over 60 år. For det andet, at det er yderst sjældent, at så tidlig en bog var trykt på gult i modsætning til gulnet papir faktisk kender jeg kun fem andre danske 1500-tals bøger på gult papir. "Og for det tredje, hvad er det for en historie, der ligger bag ved denne særbestilling af en foliobibel i 1550 på farvet papir? Hierta fremhæver selv fænomenet i et håndskrevet notat dateret 1912 på eksemplarets flyveblad: „Fullständigt och godt ex. på gult papper ... specifikt danskt". Men hvorfor en gul bibel? Ingen andre eksemplarer kendes.

Spørgsmålet om denne bibels salg fandtes i det svenske antikvariat Björk og Börjessons egne notater i deres katalog fra 1932, hvor der stod, at den blev solgt for sv.

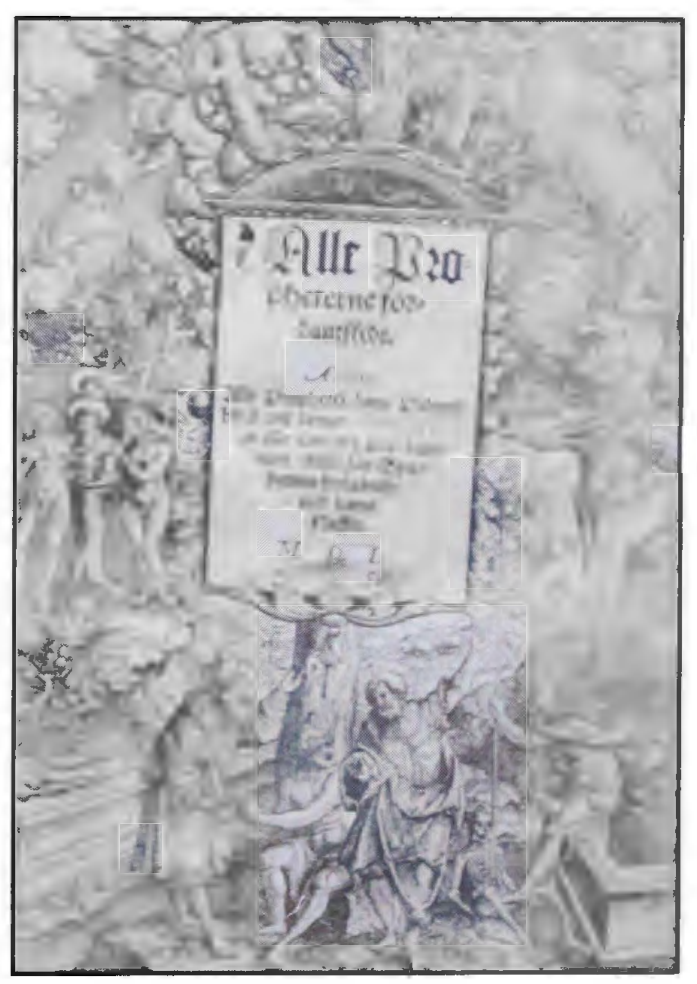

Titelbladet til „Profeterne “ $i$ Per Hiertas eksemplar af Christian III's foliobibel, hvor papiret ergulnet. 
kr. 710, men desværre ikke til hvem. Min opgave nu, alene drevet af nysgerrighed indrømmer jeg, var så at finde frem til andre eventuelle kopier af kataloget, der måske kunne indeholde flere notater angående køberens identitet. Her var jeg så heldig, at en af Bibliofilklubbens rejser i 1998 førte til Uppsala, hvor jeg nævnte min lille sag for en af Universitetets bibliotekarer. Nogle dage senere fik jeg tilsendt en fotokopi af deres katalog fra den omtalte auktion. Og dér stod i marginen lige det, jeg søgte, nemlig navnet på køberen, en generalkonsul Hjalmar Hartmann. Nu kunne jeg så igennem mine bogvenner i klubben hurtigt opspore denne kendte danske samler. Jeg fik at vide, at hans bogsamling sikkert endnu fandtes hos en af hans slægtninge her på Sjælland. En telefonsamtale afslørede, at dette var sandt og mærkeligt nok, at hele samlingen snart skulle til auktion i København, hvor jeg selv kunne tage ind og se på bøgerne. Det gjorde jeg så - som nævnt ovenfor.

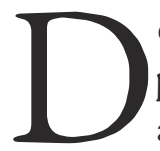
esværre var bøgerne endnu ikke pakket ud, men jeg fik arrangeret, at nogle af os, der er særligt interesseret i de helt gamle udgaver, senere kunne studere klenodierne og især denne såkaldte gule bibel. Resultatet blev, som de fleste af os havde mistanke om, at det viste sig at være en bog, der var blevet restaureret. På et tidspunkt i dens lange liv - nok i 1700-tallet - var den blevet så slidt af flittig brug i kirken, at man var nødt til både at skære de lasede ydre marginer ind til marginalnoterne, for så at afvaske alle 552 blade for snavs inden ombinding - en ret almindelig behandling af gamle, værdifulde bøger - og, væsentligst i vor sammenhæng, derefter at behandle det nyvaskede, bløde papir med en blanding af gelatine og alun, som en kemisk proces så har gulnet. Dette bekræftes delvis af den ekstra stivhed papiret har i forhold til de mange andre eksemplarer, jeg har studeret; det er „hårdt og klangfuldt".

\section{Itså Per Hierta har simpelthen taget fejl. Som nævnt før, rigtig gult papir, 1 Lendda også blåt ${ }^{21}$, er kendt i andre} tidlige udgaver, men det ville sandsynligt have drejet sig om flere eksemplarer, næppe et isoleret eksemplar som her. ${ }^{3)}$ Hierta skriver også, at „Raritetsexemp. på gult och grönt papper är specifikt danskt. "Er dette rigtigt? Helt gule bøger har jeg, som sagt, selv set, men grønne - og så specielt fra Danmark? ${ }^{21}$ Kan nogen give mig yderligere oplysninger?

Bogen blev i øvrigt købt på auktionen af et ledende københavnsk antikvariat til en meget rimelig pris, og er siden havnet $\mathrm{i}$ en privat dansk samling, måske ikke i original stand, men dog en komplet Christian den Tredje og så med en ganske interessant historie tilknyttet.

Noter:

1) a) Veit Dietrich (Vitus Theodorus), En enfoldig underuisning paa Fader vor, .... hoss Jurgen Rhaws Arffinge, Wittemberg, 1552. Oc findis til kiøbs hoess Pauel Knufflock (Poul Knobloch) Boge=binder i Lybeck.

LN 527, KB 4,-93 DA box. (Papiret, der hverken er stift eller glittet, er jævnt farvet helt igennem.)

b) En deylig Bone Bog, Peder Tidemand, København 1563.

LN 457, Thesaurus I, 103. „Gelb getöntes Papier hat auch das Exemplar der Universitätsbibliothek Uppsala": Die Lübecker Buchdrucker im 15. und 16. Jahrhundert. Buchdruck für den Ostseeraum nr. 44. Alken Bruns \& Dieter Lohmeier, Heide in Holstein.

c) Lucas Martini: Alle Christelige oc dydelige Jomfruers arekrantz. Kiøbenhaffn, Lorentz Benedicht, 1594. 
LN 1149, Thesaurus I, 137. Findes på Skokloster, Sverige. Kun 3 andre eksemplarer er registreret, dette på gult papir er nok unikt.

d) M. Luther: Hortulus Anima. Sialens Urtegaard met deylige figurer oc Kalendario. Peder Tidemand, Wittenberg, 1552.

LN 954, Thesaurus I, 77. (Papiret i dette eksemplar i private hænder i Danmark er jævnt farvet helt igennem, men kan være gulnet med alderen.)

e) Nye testamente paa Danske. Wittenberg, 1558.

LN 1568, Thesaurus I, 96. KB TH 29439.
2) Et eksemplar på blåt papir af Vergilius Maros opera, Venedig, in ædibus Aldi et Andrex soceri, 1514, findes i Sotheby's katalog fra 26.6.86, nr. 128. Den solgtes for $£ 14.000$.

3) Men særlige præsentationseksemplarer trykt på pergament af vigtige værker er ikke ualmindelige.

4) Dog findes der i Sotheby's bogkatalog fra 28.6.91, nr. 600, et 1563 tysk Ny Testamente trykt af Zöpfel \& Rasch i Frankfurt og med samtidigt bind, som er "printed on an extraordinary shade of bright green paper, "i følge Charlotte Brown, Sotheby's. Den gik for $£ 11.000$. 